OPEN ACCESS

Edited by:

Eric Tartour,

Hôpital Européen Georges-

Pompidou, France

Reviewed by:

Wolfgang Kastenmüller,

Universität Würzburg, Germany

Brian S. Sheridan,

Stony Brook University,

United States

*Correspondence: Björn Rissiek

b.rissiek@uke.de;

Friedrich Koch-Nolte

nolte@uke.de

Specialty section:

This article was submitted to Immunological Memory,

a section of the journal

Frontiers in Immunology

Received: 31 March 2018 Accepted: 26 June 2018 Published: 09 July 2018

Citation:

Rissiek B, Lukowiak M, Raczkowski F

Magnus T, Mittrücker $\mathrm{H}-\mathrm{W}$ and

Koch-Nolte F (2018) In Vivo Blockade of Murine ARTC2.2 During Cell

Preparation Preserves the

Vitality and Function of Liver

Tissue-Resident Memory T Cells.

Front. Immunol. 9:1580.

doi: 10.3389/fimmu.2018.01580

\section{In Vivo Blockade of Murine ARTC2.2 During Cell Preparation Preserves the Vitality and Function of Liver Tissue-Resident Memory T Cells}

\author{
Björn Rissiek ${ }^{1 *}$, Marco Lukowiak ${ }^{1}$, Friederike Raczkowski ${ }^{2}$, Tim Magnus ${ }^{1}$, \\ Hans-Willi Mittrücker ${ }^{2}$ and Friedrich Koch-Nolte ${ }^{2 *}$ \\ ${ }^{1}$ Department of Neurology, University Medical Center, Hamburg-Eppendorf, Hamburg, Germany, ${ }^{2}$ Institute of Immunology, \\ University Medical Center, Hamburg-Eppendorf, Hamburg, Germany
}

On murine T cells, GPI-anchored ADP-ribosyltransferase 2.2 (ARTC2.2) ADP-ribosylates the P2X7 ion channel at arginine 125 in response to nicotinamide adenine dinucleotide $\left(\mathrm{NAD}^{+}\right)$released during cell preparation. We have previously shown that chronic gating of P2X7 by ADP-ribosylation reduces the vitality and function of regulatory $T$ cells and natural killer T cells that co-express high levels of ARTC2.2 and P2X7. Here, we evaluated the expression of ARTC2.2 and P2X7 by effector and memory T cells in the liver of naive mice and after infection with Listeria monocytogenes $(L \mathrm{~m})$. We found that $\mathrm{KLRG1}^{-} / \mathrm{CD} 9^{+}$tissue-resident memory $\mathrm{T}$ cells (Trm) in the liver of naïve mice and 7 weeks after infection with Lm express high levels of ARTC2.2 and P2X7. Isolation of liver Trm and subsequent incubation at $37^{\circ} \mathrm{C}$ resulted in cell death of the majority of $\mathrm{CD}^{+}{ }^{+}$and $\mathrm{CD}^{+}{ }^{+}$Trm. Injection of the ARTC2.2-blocking nanobody s+16a 30 min prior to organ harvesting effectively prevented ADP-ribosylation of P2X7 during cell preparation and thereby prevented NAD-induced cell death of the isolated Trm upon subsequent incubation at $37^{\circ} \mathrm{C}$. Consequently, preserving Trm vitality by s+16a injection enabled a highly sensitive in vitro cytokine expression profile analyses of FACS sorted liver Trm. We conclude that in vivo blockade of ARTC2.2 during cell preparation by nanobody s+16a injection represents a valuable strategy to study the role and function of liver Trm in mice.

Keywords: ADP-ribosylation, P2X7, tissue-resident memory T cells, nanobodies, ARTC2.2

\section{INTRODUCTION}

Mammalian ecto-ADP-ribosyltransferases (ecto-ARTs) are a family of toxin-related enzymes that use extracellular $\left(\mathrm{NAD}^{+}\right)$to attach an $\mathrm{ADP}$-ribose group to arginine residues of cell surface proteins. In mice, the ecto-ARTs family comprises six family members (ARTC1-5) including two isoforms of ARTC2, termed ARTC2.1 and ARTC2.2 that are encoded by two closely linked genes (Art2a and Art2b) (1). ARTC2 isoforms are expressed on immune cells. While ARTC2.1 is expressed mainly by innate immune cells such as macrophages, dendritic cells, and microglia, ARTC2.2 is the major ecto-ART expressed by T cells (2-4). The ARTC2 enzymes ADP-ribosylate various target proteins and thereby modulate their function. One well-characterized target of ARTC2.2-mediated ADPribosylation is the adenosine triphosphate (ATP)-gated P2X7 ion channel $(5,6)$. Two differentially spliced isoforms of $\mathrm{P} 2 \mathrm{X} 7$ are expressed by murine immune cells $(7,8)$. P2X7a is expressed by innate 
immune cells and plays a critical role in inflammasome formation and the release of mature interleukin (IL)-1 $\beta$ from these cells. P2X7k is expressed by T cells where ADP-ribosylation of P2X7 at R125 can trigger gating of P2X7k at much lower concentrations of $\mathrm{NAD}^{+}$compared to ATP (9). ATP and ADP-ribosylationmediated gating of $\mathrm{P} 2 \mathrm{X} 7$ on $\mathrm{T}$ cells induces the rapid influx of calcium, activation of cell surface metalloproteases, cleavage of cell surface ecto-domains of CD62L (10) and CD27 (11), externalization of phosphatidylserine, and ultimately cell death (5).

Several studies have shown that the ecto-ART substrate $\mathrm{NAD}^{+}$ can be released from endogenous sources, e.g., via cell lysis or, in a more controlled fashion, via connexin hemichannels $(12,13)$. We have previously demonstrated that $\mathrm{NAD}^{+}$is released during the passage of cell culture cells and the preparation of primary leukocytes from murine spleen, lymph nodes, or the liver $(12,14)$. Of note, ARTC2 is catalytically active and ADP-ribosylates cell surface proteins, including $\mathrm{P} 2 \mathrm{X} 7$, even if cells are prepared at $4^{\circ} \mathrm{C}$ (12). Gating of P2X7 by ADP-ribosylation, however, requires temperatures above $24^{\circ} \mathrm{C}$, i.e., functional effects of P2X7 ADPribosylation on $\mathrm{T}$ cells are manifested during reincubation of isolated $\mathrm{T}$ cells at $37^{\circ} \mathrm{C}$. This commonly results in cell death of a substantial fraction of T cells (12), in particular T cell populations that co-express high levels of ARTC2.2 and P2X7 such as regulatory $\mathrm{T}$ cells (Tregs) and natural killer T cells (NKTs) (14, 15). ADP-ribosylation of P2X7 during cell preparation affects the vitality of these cells and makes it difficult to use them for further in vitro functional assay or for adoptive transfer experiments (16). We recently described an experimental approach to prevent preparation-related ADP-ribosylation by systemic injection of the ARTC2.2-blocking nanobody s+16a, a $15 \mathrm{kDa}$ small single domain antibody derived from llama heavy chain antibodies $(14,17)$. Injection of $s+16 a 30$ min prior to sacrificing the mice prevents the detrimental effects of preparation-related P2X7 ADP-ribosylation and facilitates the use of freshly prepared Tregs and NKTs for functional assay and adoptive transfer experiments.

Tissue-resident memory T cells (Trm) comprise a population of $\mathrm{T}$ cells, which stays in peripheral tissues after an immune response against invading pathogens, forming a rapid first-line defense against recurring infection (18). Trm are characterized by cell surface expression of CD69 and lack of cell surface expression of the killer cell lectin-like receptor subfamily G member 1 (KLRG1) (19). A recent study suggests that cell preparation affects the vitality and function of this $\mathrm{T}$ cell population in the context of a malaria mouse model (20). In our present study, we analyzed liver Trm from naïve mice and from mice 7 weeks after Listeria monocytogenes $(\mathrm{Lm})$ infection in order to increase the number of Trm in the liver. In both, we analyzed the expression of ARTC2.2 and P2X7. We tested the impact of the ARTC2.2-blocking nanobody s+16a on the vitality of Trm vitality and on the functional capacity of freshly prepared Trm to secrete cytokines. Our results demonstrate that $\mathrm{CD} 8^{+}$and $\mathrm{CD} 4^{+}$liver Trm co-express high levels of ARTC2.2 and P2X7 and that preparation of primary Trm from liver causes ADP-ribosylation of $\mathrm{P} 2 \mathrm{X} 7$ resulting in cell death in the majority of isolated $\mathrm{CD}^{+}$and $\mathrm{CD}^{+}$Trm upon incubation at $37^{\circ} \mathrm{C}$. Systemic injection of nanobody s+16a preserved Trm vitality and allowed sensitive monitoring of otherwise unnoticed cytokine expression.

\section{MATERIALS AND METHODS}

\section{Mice}

C57BL/6 mice were used for all experiments. ARTC2ko mice (21) and P2X7 mice (22) were backcrossed onto the C57BL/6J background for at least 12 generations. Splenocytes from RAG1ko mice (23) were used as feeder cells in some experiments. All mice were bred at the animal facility of the University Medical Center (UKE). All experiments involving tissue derived from animals were performed with approval of the responsible regulatory committee (Hamburger Behörde für Gesundheit und Verbraucherschutz, Veterinärwesen/Lebensmittelsicherheit, G17/17). All methods were performed in accordance with the relevant guidelines and regulations.

\section{Lm Infection}

C57BL/6 mice were intravenously (i.v.) infected with a Lm strain recombinant for ovalbumin $\left(2 \times 10^{4}\right.$ bacteria in $\left.200 \mu \mathrm{PBS}\right)(24)$. Mice were housed under specific pathogen-free conditions in individually ventilated cages, received food and water ad libitum and were controlled on a daily basis during the experiment.

\section{Nanobody s+16a Treatment}

$s+16$ a was recombinantly produced by transfecting HEK-6E cells with the pCSE2.5 vector containing the coding region of $s+16 \mathrm{a}$. Mice were injected i.v. with $50 \mu \mathrm{g}$ of the ARTC2.2-blocking nanobody s+16a solved in $100 \mu \mathrm{l} \mathrm{NaCl} 30$ min prior to sacrificing the mice in order to prevent ADP-ribosylation of P2X7 during cell preparation.

\section{Preparation of Liver Trm}

Mice were anesthetized by $\mathrm{CO}_{2} / \mathrm{O}_{2}$ exposure and sacrificed by cervical dislocation. The preparation of single-cell suspensions from liver was performed throughout at $4^{\circ} \mathrm{C}$. Liver lobes were gently mashed through a metal sieve using a syringe piston. Purification of liver leukocytes was achieved by running a Percoll gradient. For this, cells were resuspended in $5 \mathrm{ml} \mathrm{33 \%} \mathrm{Percoll/}$ PBS in a $15-\mathrm{ml}$ Falcon tube, and centrifuged at $1,600 \mathrm{rpm}, 12^{\circ} \mathrm{C}$, for $20 \mathrm{~min}$ without breaks. The pellet was collected, and cells were washed once in PBS (ThermoFisher). Contaminating erythrocytes were lysed using ACK erythrocyte lysis buffer $(155 \mathrm{mM}$ $\mathrm{NH}_{4} \mathrm{Cl}, 10 \mathrm{mM} \mathrm{KHCO} 3,0.1 \mathrm{mM}$ EDTA, pH 7.2). For FACS analyses or sorting, cells were washed and resuspended in FACS buffer containing PBS, $1 \mathrm{mM}$ EDTA (Sigma), and $0.1 \%$ bovine serum albumin (Sigma).

\section{Antibodies and Flow Cytometry}

The following antibodies were used for flow cytometric analyses: anti-ARTC2.2 (clone Nika109; UKE), anti-CD3 (clone 145-2C11, BioLegend), anti-CD4 (clone RM4-5, BioLegend), anti-CD8 (clone 53-6.7, BioLegend), anti-CD45 (clone30-F11, BioLegend), anti-CD69 (clone H1.2F3, BioLegend), anti-KLRG1 (clone 2F1/ KLRG1, BioLegend), and anti-P2X7 (clone RH23A44, UKE). PE-labeled CD1d-tetramer (PBS-57-loaded) was kindly provided by the NIH tetramer core facility. Flow cytometric analyses were performed on a BD Fortessa (Beckton Dickinson) or a BD 
FACS CantoII (Beckton Dickinson). Liver Trm were identified as $\mathrm{CD}^{+}{ }^{+} \mathrm{CD} 69^{+} \mathrm{KLRG}^{-}$or $\mathrm{CD}^{+}{ }^{+} \mathrm{CD} 69^{+} \mathrm{KLRG}^{-}$, and tissue residency was probed by applying the anti-CD45 in vivo labeling technique (25). For this, $2 \mu \mathrm{g}$ of fluorochrome-labeled antiCD45-perCP solved in $100 \mu \mathrm{l}$ PBS were intravenously injected into mice, which were sacrificed 3 min after injection. After cell preparation, all leukocytes were labeled with anti-CD45-PE-Cy7 and blood vessel resident cells were identified as CD45-PE$\mathrm{Cy}^{+} \mathrm{CD} 45$-perCP ${ }^{+}$. For some experiments, liver Trm were sorted at the FACS Core Facility at the University Medical Center Hamburg-Eppendorf (UKE) on a BD FACSAriaFusion (Beckton Dickinson). Analysis of flow cytometric data was performed using FlowJo X (Flowjo, LLC).

\section{Monitoring P2X7-Induced Cell Death}

$\mathrm{CD}^{+}{ }^{+} \mathrm{CD} 69^{+} \mathrm{KLRG}^{-}, \quad \mathrm{CD} 4^{+} \mathrm{CD} 69^{-} \mathrm{KLRG}^{+}, \quad \mathrm{CD} 8^{+} \mathrm{CD} 69^{+}$ $\mathrm{KLRG1}^{-}$, and $\mathrm{CD} 8^{+} \mathrm{CD} 69^{-} \mathrm{KLRG1}^{+}$cells were FACS sorted and $1 \times 10^{4}$ cells were resuspended in $200 \mu \mathrm{l}$ complete IMDM medium containing IMDM (ThermoFisher) $+5 \%$ FCS, $\beta$-mercaptoethanol (50 $\mu \mathrm{M}$, ThermoFisher), and gentamicin $(50 \mu \mathrm{g} / \mathrm{ml}$, ThermoFisher). For some experiments, FACS sorted Trm were cultured in the presence of $2 \times 10^{5}$ eFluor ${ }^{670}$-labeled feeder cells obtained from RAG1ko mice in a ration of 1:20. Cells were incubated for $2 \mathrm{~h}$ at $4^{\circ} \mathrm{C}$ on ice or at $37^{\circ} \mathrm{C}$ in a cell culture incubator in the presence of propidium iodide (PI, $2.5 \mu \mathrm{g} / \mathrm{ml}$, ImmunoChemistry Technologies, LLC). PI uptake was used to determine cell death by flow cytometry directly after incubation.

\section{Cytokine Secretion Assay}

$\mathrm{CD}^{+}{ }^{+} \mathrm{CD} 69^{+} \mathrm{KLRG1}^{-}$and $\mathrm{CD}{ }^{+}{ }^{+} \mathrm{CD} 69^{+} \mathrm{KLRG1}^{-}$Trm were isolated by FACS sorting from mice 7 weeks after infection with $\mathrm{Lm}$. Isolated Trm were cultured in $200 \mu \mathrm{l}$ IMDM (ThermoFisher) $+5 \%$ FCS, $\beta$-mercaptoethanol ( $50 \mu \mathrm{M}$, ThermoFisher), and gentamicin $\left(50 \mu \mathrm{g} / \mathrm{ml}\right.$, ThermoFisher) at a cell density of 20,000 (CD4 ${ }^{+}$Trm $)$ or $10,000\left(\mathrm{CD}^{+}\right.$Trm $)$cells per well for $20 \mathrm{~h}$ in the presence of Phorbol 12-myristate 13-acetate (PMA, $20 \mathrm{ng} / \mathrm{ml}$, Invivogen) and ionomycin $(1 \mu \mathrm{g} / \mathrm{ml}$, Invivogen $)$ to induce cytokine expression. Levels of IFN- $\gamma$, TNF- $\alpha$, IL-2, IL-4, IL-21, IL-22, IL-17A, IL-17F, IL-10, IL-9, IL-5, and IL-13 were measured in the supernatants of stimulated Trm by using the LEGENDplex mouse Th cytokine 13-plex (BioLegend) according to the manufacture's instruction.

\section{RESULTS}

\section{Liver Trm Co-Express ARTC2.2 and P2X7}

Tissue-resident memory $\mathrm{T}$ cells (Trm) are a population of noncirculating $\mathrm{CD}^{+}$and $\mathrm{CD} 8^{+} \mathrm{T}$ cells that stay in peripheral tissues after infection to build a rapid first-line defense against recurring pathogen invasion (18). A recent study suggests that liver CD8 ${ }^{+}$ Trm are affected by $\mathrm{NAD}^{+}$released during cell preparation (20), however, these cells have not yet been fully characterized toward their expression of ARTC2.2 and P2X7. Since co-expression of ARTC2.2 and P2X7 potentially renders cells susceptible toward $\mathrm{NAD}^{+}$-induced cell death (5), we set out to measure ARTC2.2 and $\mathrm{P} 2 \mathrm{X} 7$ expression on these cells. In order to increase the frequency of liver Trm, we infected mice i.v. with $\mathrm{Lm}$ and analyzed liver $\mathrm{CD} 4^{+}$ and $\mathrm{CD}^{+}$Trm 7 weeks after infection (Figure 1A). $\mathrm{CD}^{+}$and
$\mathrm{CD}^{+}$Trm were identified as $\mathrm{CD}^{+} \mathrm{CD} 1 \mathrm{~d}^{\text {tet- }} \mathrm{T}$ cells that express CD69 but lack KLRG1 expression. Conversely, CD69-KLRG1 ${ }^{+}$ $\mathrm{T}$ cells were identified as effector memory $\mathrm{T}$ cells (Tem). The remaining CD69-KLRG1- T cells were termed "double negative" (DN) including naïve and memory T cells (Figure 1B). In order to distinguish vascular T cells and from tissue-resident $\mathrm{T}$ cells, we injected anti-CD45-perCP antibodies 3 min prior to sacrificing the mice. Due to the fenestrated endothelium of the liver sinusoids, anti-CD45-perCP in vivo labeling (termed CD45 $5^{\text {blood }}$ ) led to a low-level CD45 staining of all CD45 ${ }^{+}$liver leukocytes (termed $\left.\mathrm{CD}^{2} 5^{\text {all }}\right)$. However, when comparing $\mathrm{CD}^{+}$and $\mathrm{CD} 4^{+}$Trm with Tem or DN T cells, only Tem and DN T cells contained a substantial fraction of cells that were strongly labeled by the i.v. injected anti-CD45-perCP antibody, confirming that CD69 ${ }^{+} \mathrm{KLRG}^{-}$Trm reside deeper in the liver tissue (Figure 1C). Seven weeks after $\mathrm{Lm}$ infection, the frequencies of $\mathrm{CD}^{+} \mathrm{Trm}$ and Tem as well as of $\mathrm{CD}^{+}$Trm were significantly increased compared to naïve mice (Figure 1D). We next, analyzed these three subpopulations of $\mathrm{CD}^{+}$and $\mathrm{CD}^{+} \mathrm{T}$ cell populations obtained from naïve mice and 7 weeks after Lm infection for expression of ARTC2.2 and P2X7 using specific monoclonal antibodies $(26,27)$. In naïve mice, a substantial fraction of $\mathrm{CD}^{+}$and $\mathrm{CD} 4^{+}$Trm co-express high levels of ARTC2.2 and P2X7 (Figure 1E). By contrast, most $\mathrm{CD}^{+}$and $\mathrm{CD}^{+}$Tem and DN cells express ARTC2.2 but lack P2X7 expression. Seven weeks after Lm infection, we found that the majority of $\mathrm{CD}^{+}$and $\mathrm{CD} 4^{+}$Trm co-express high levels of ARTC2.2 and P2X7. By contrast, most $\mathrm{CD}^{+}$and $\mathrm{CD}^{+}{ }^{+} \mathrm{Tem}$ express only low levels of ARTC2.2 and P2X7. Furthermore, DN $\mathrm{CD}^{+}$and $\mathrm{CD}^{+} \mathrm{T}$ cells do not express substantial levels of P2X7 but a major fraction of $\mathrm{CD}^{+}(>80 \%)$ and $\mathrm{CD}^{+}(>60 \%) \mathrm{DN}$ $\mathrm{T}$ cells expresses high levels of ARTC2.2. In summary, $\mathrm{CD}^{+}$and $\mathrm{CD}^{+}$liver Trm co-express high levels of ARTC2.2 and P2X7, especially when isolated 7 weeks after Lm infection (Figure 1F), and therefore are potentially sensitive toward $\mathrm{NAD}^{+}$released during cell preparation.

\section{Injection of $s+16$ a Preserves the Vitality of Isolated Liver Trm}

T cells co-expressing high levels of ARTC2.2 and P2X7, such as Treg and NKT cells, are highly susceptible to $\mathrm{NAD}^{+}$-released during cell preparation, resulting in reduced vitality and function of the isolated cells $(14,16)$. Extracellular $\mathrm{NAD}^{+}$released during cell preparation serves as substrate for ARTC2.2 catalyzing the ADP-ribosylation of R125 of P2X7, even when cells are prepared at $4^{\circ} \mathrm{C}$ (Figure 2A). When cells are brought back to $37^{\circ} \mathrm{C}$, e.g., for functional assays or adoptive transfer, ADP-ribosylation of P2X7 triggers channel gating leading to influx of $\mathrm{Ca}^{2+}$ and ultimately to cell death which can be visualized by PI uptake. ADP-ribosylation of P2X7 during cell preparation can be prevented by injection of the ARTC2.2-blocking nanobody s+16a $30 \mathrm{~min}$ prior to organ harvesting. Since liver Trm co-express high levels of ARTC2.2 and P2X7, we hypothesized that preparationrelated ADP-ribosylation of $\mathrm{P} 2 \mathrm{X} 7$ reduces the vitality of these cells upon reincubation at $37^{\circ} \mathrm{C}$. To test this, we first isolated Trm from the liver of naïve WT, ARTC2ko, and P2X7ko mice via FACS and incubated the isolated cells for $2 \mathrm{~h}$ in IMDM $+5 \%$ FCS in the presence of PI at $37^{\circ} \mathrm{C}$ or kept the cells at $4^{\circ} \mathrm{C}$ on ice. 
A

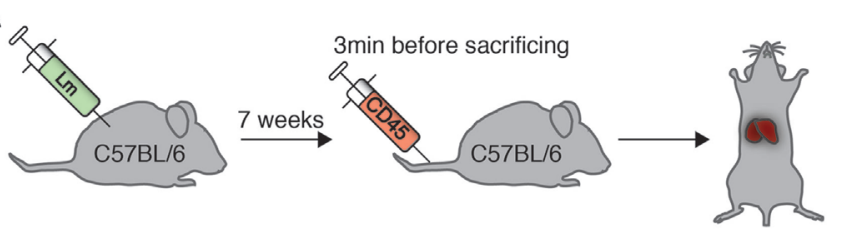

E

naive mice

B
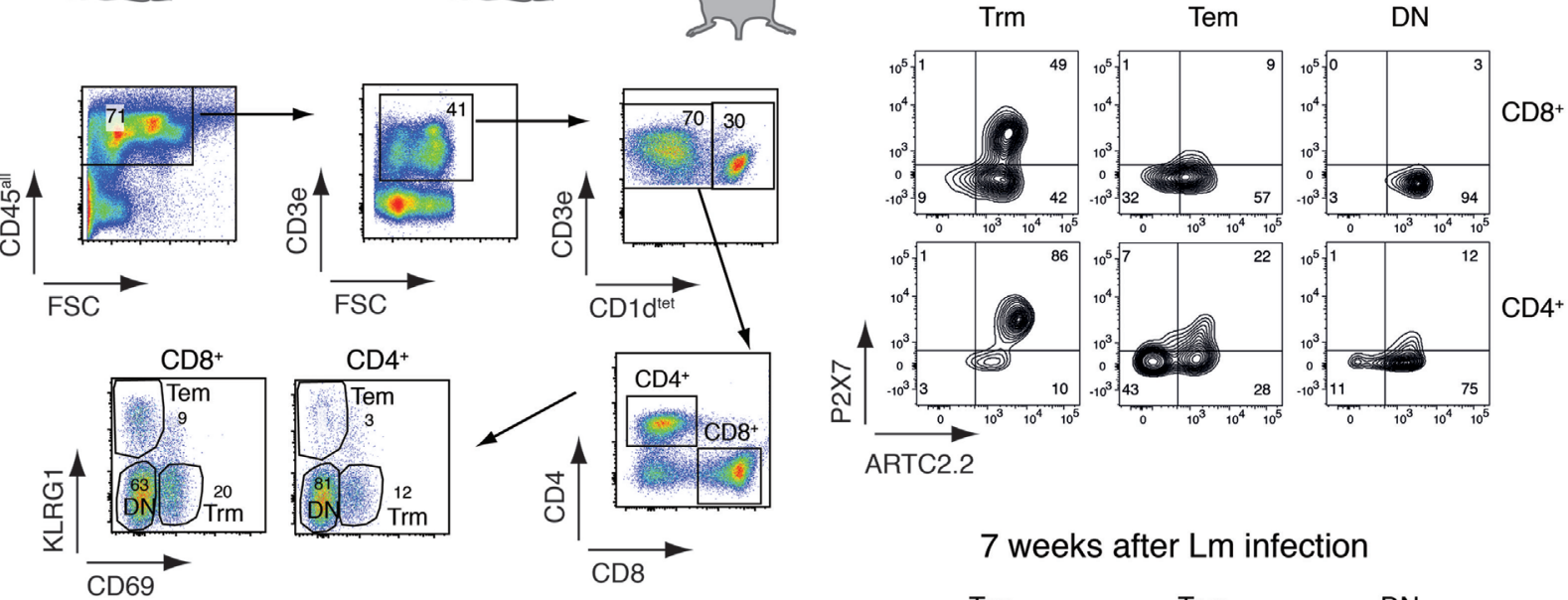

7 weeks after Lm infection

C
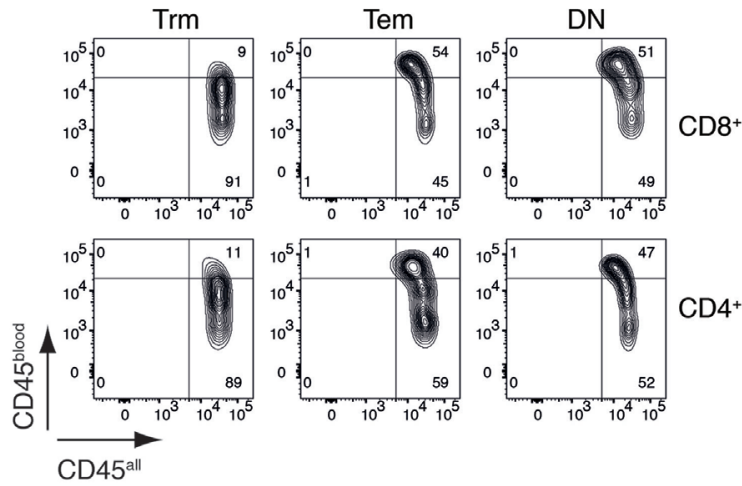

D
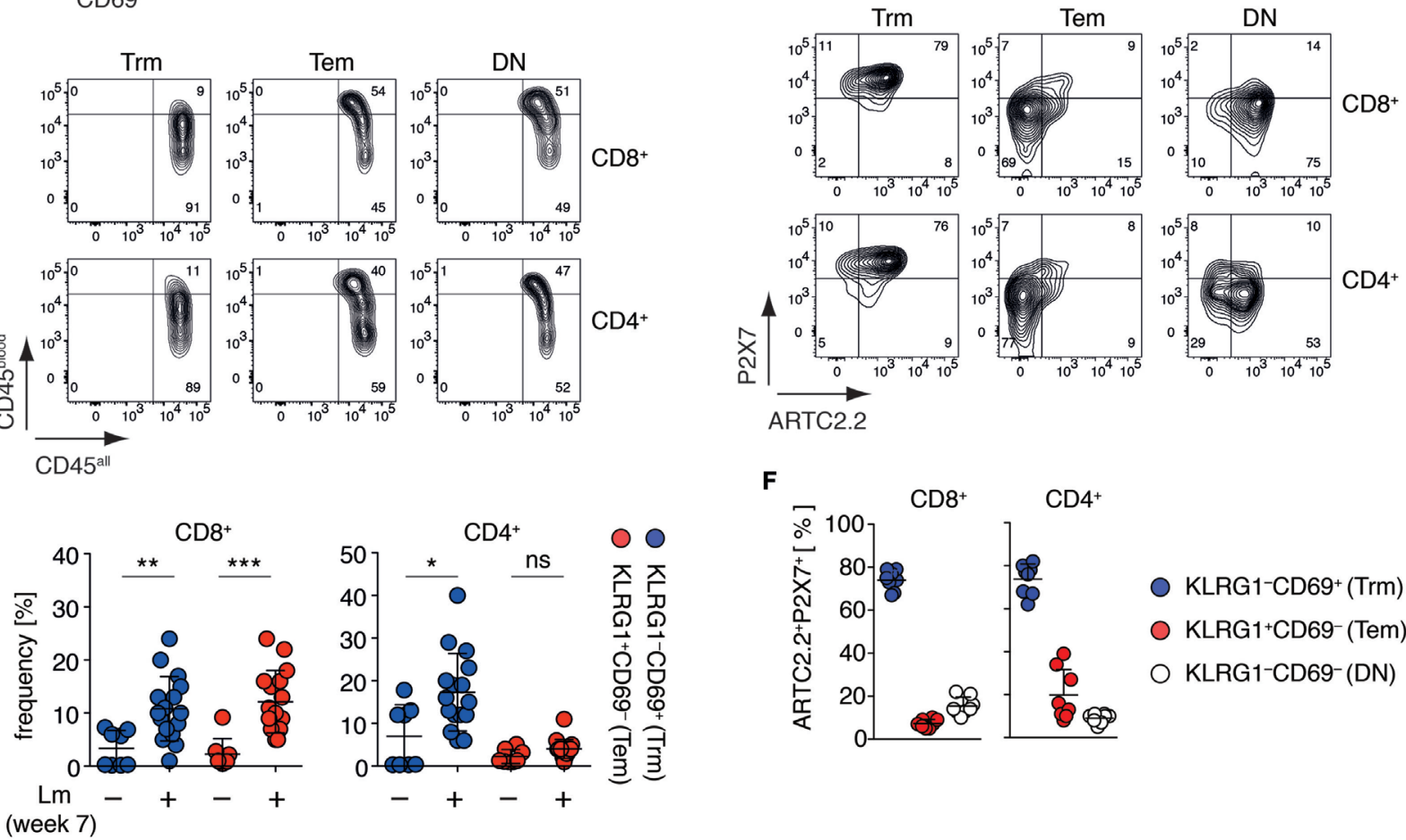

$\mathbf{F}$

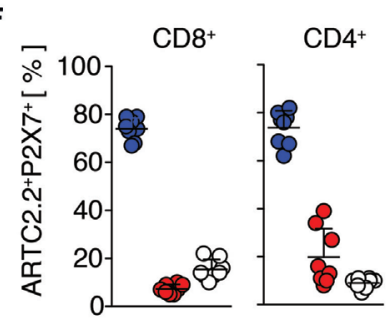

KLRG1-CD69+(Trm)

$\mathrm{KLRG}_{1+\mathrm{CD} 69}{ }^{-}$(Tem)

O KLRG1-CD69-(DN)

FIGURE 1 | Liver Trm co-express high levels of ARTC2.2 and P2X7. (A) C57BL/6 mice were infected i.v. with $2 \times 10^{4}$ Listeria monocytogenes (Lm). Seven weeks after infection, mice were treated with perCP-labeled anti-CD45 $3 \mathrm{~min}$ before sacrificing to label vascular leukocytes. The liver of treated mice was harvested for Trm analyses. (B) Gating strategy: within the $\mathrm{CD} 3^{+} \mathrm{CD} 1 \mathrm{~d}^{\mathrm{tet}-} \mathrm{T}$ cell pool Trm were identified as $\mathrm{CD} 8^{+} \mathrm{CD} 69^{+} \mathrm{KLRG} 1^{-}$or $\mathrm{CD} 4^{+} \mathrm{CD} 69^{+} \mathrm{KLRG} 1^{-}$and effector memory $T$ cells (Tem) as CD8 ${ }^{+} \mathrm{CD} 69-\mathrm{KLRG}^{+}$or $\mathrm{CD} 4^{+} \mathrm{CD} 69^{-} \mathrm{KLRG1} 1^{+}$; double negative (DN) marks CD8 ${ }^{+}$or $\mathrm{CD} 4^{+} \mathrm{T}$ cells that were CD69-KLRG1-. (C) In vivo anti-CD45 labeling (CD45 ${ }^{\text {blood }}$ of Trm, Tem, and DN in relation to ex vivo anti-CD45 labeling (CD45 all). (D) Frequencies of CD8 ${ }^{+}$and CD4+ Trm and Tem in the liver of naiive and $L m$ infected mice. Two groups were compared using Student's $t$-test $(n=8-16)$ with ${ }^{*} p<0.05,{ }^{* *} p<0.01,{ }^{* \star *} p<0.001$. (E) FACS analyses of ARTC2.2 and P2X7 expression on Trm, Tem, and DN cells from naïve mice (upper panel) and mice 7 weeks after infection with Lm (lower panel). (F) Frequency of ARTC2.2 and P2X7 co-expressing cells from mice 7 weeks after $\mathrm{Lm}$ infection are quantified as \% of $\mathrm{CD} 4^{+}$or $\mathrm{CD} 8^{+} \mathrm{T}$ cells. The shown data represent results from at least two independently performed experiments.

PI uptake by Trm was subsequently analyzed by flow cytometry as a measure for cell death. We observed that the majority of WT $\mathrm{CD}^{+}$and $\mathrm{CD}^{+} \mathrm{Trm}$ died upon incubation at $37^{\circ} \mathrm{C}$ as shown by incorporation of PI. This discrepancy in vitality upon incubation at 4 and $37^{\circ} \mathrm{C}$ was virtually absent when analyzing $\mathrm{CD}^{+}$and $\mathrm{CD}^{+}$Trm from ARTC2ko and P2X7ko mice (Figure 2B). To 


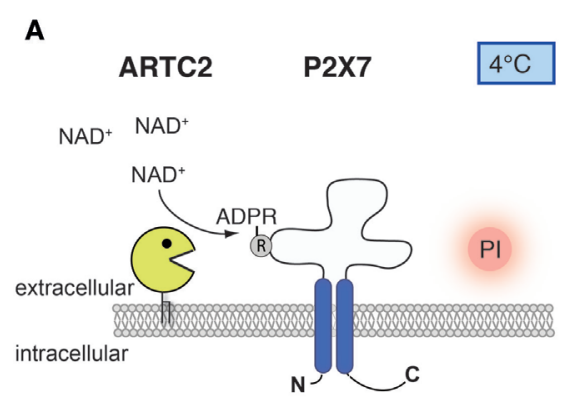

B

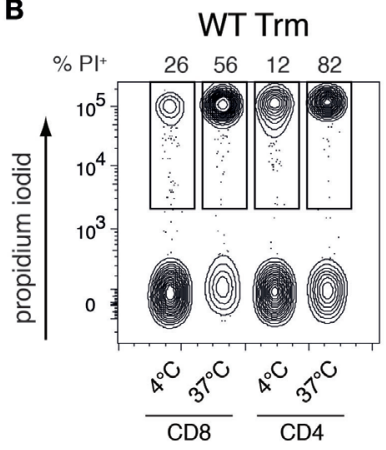

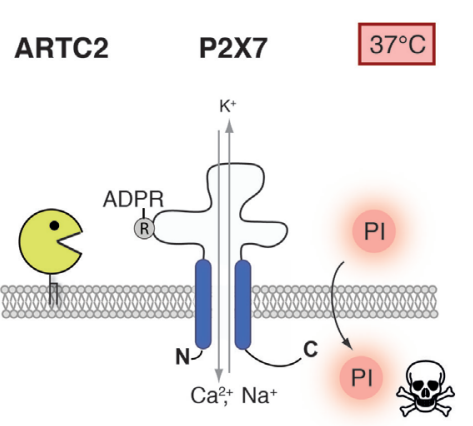

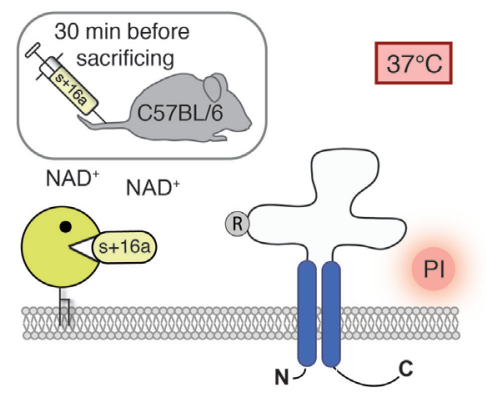

C

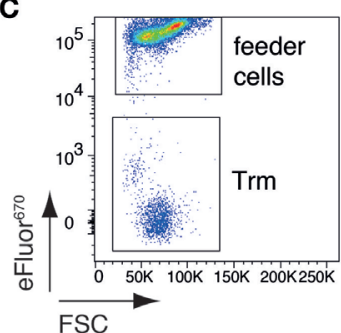

ARTC2ko Trm

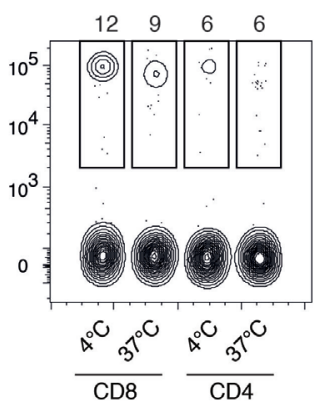

$\mathrm{CD}^{+}{ }^{+} \mathrm{Trm}$

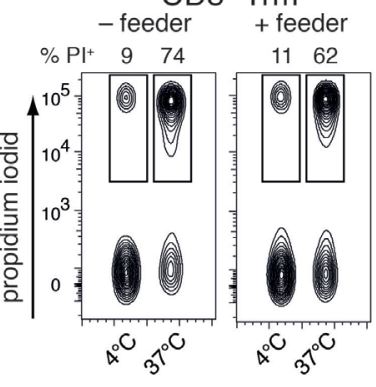

P2X7ko Trm

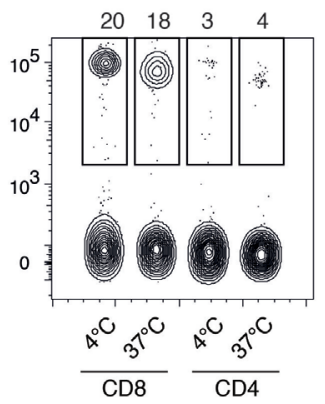

$\mathrm{CD}^{+}{ }^{+} \mathrm{Trm}$

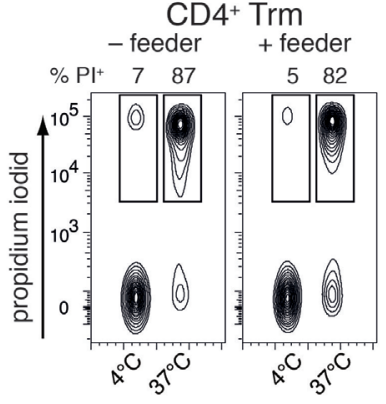

D

CD8 + Trm

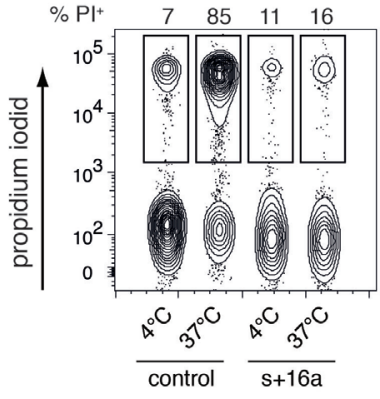

$\mathrm{CD}^{+}$Trm

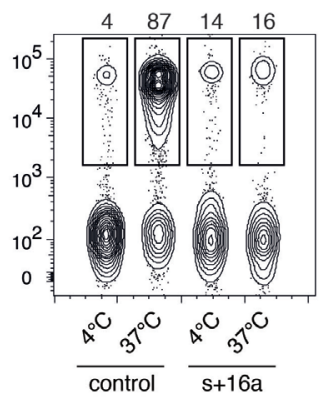

CD8+ Tem

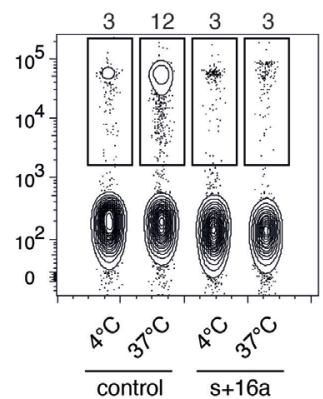

$\mathrm{CD}^{+}$Tem

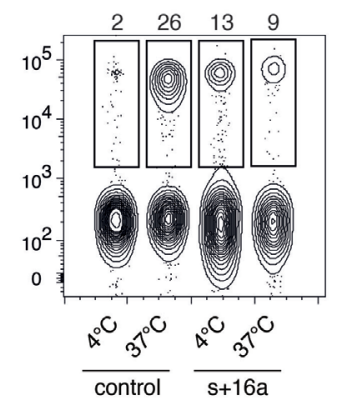

FIGURE 2 | ADP-ribosylation of Trm during cell preparation induces cell death upon $37^{\circ} \mathrm{C}$ incubation. (A) $\mathrm{NAD}^{+}$is released during cell preparation and serves as substrate for ARTC2.2 to ADP-ribosylate P2X7 at R125, even if cells are prepared at $4^{\circ} \mathrm{C}$. ADP-ribosylation-mediated gating of P2X7 occurs when cells are brought back to $37^{\circ} \mathrm{C}$, inducing $\mathrm{Ca}^{2+}$ influx and ultimately cell death. ADP-ribosylation of P2X7 during cell preparation and subsequent activation of $\mathrm{P} 2 \mathrm{X} 7$ at $37^{\circ} \mathrm{C}$ can be prevented by injection of the ARTC2.2-blocking nanobody s+16a 30 min prior to sacrificing the mice. (B) CD8 ${ }^{+}$and CD4+ Trm were isolated via FACS from the liver of naïve WT, ARTC2ko, and P2X7ko mice. Cells were incubated at $37^{\circ} \mathrm{C}$ for $2 \mathrm{~h}$ and propidium iodide (PI) uptake was measured by flow cytometry as marker for cell death. (C) Isolated CD8 ${ }^{+}$and CD4+ Trm from the liver of naïve WT mice were cultured in the presence or absence of eFluor ${ }^{670}-$ labeled feeder cells in a ration of 1:20. Cells were incubated at $37^{\circ} \mathrm{C}$ for $2 \mathrm{~h}$ and PI uptake by Trm was measured by flow cytometry as marker for cell death. (D) CD8 ${ }^{+}$and CD4+ Trm and effector memory T cells (Tem) were isolated via FACS from the liver of Lm infected mice 7 weeks after infection. One group of mice was treated with s+16a prior to organ harvesting and the second group was left untreated as control. Cells were incubated at $37^{\circ} \mathrm{C}$ for $2 \mathrm{~h}$ and $\mathrm{PI}$ uptake was measured by flow cytometry as marker for cell death. The shown data represent results from two independently performed experiments. 
further test whether the presence of feeder cells could improve the vitality of Trm, we co-incubated FACS-sorted WT CD8 ${ }^{+}$ and $\mathrm{CD}^{+}$Trm with eFluor ${ }^{670}$-labeled splenocytes obtained from RAG1ko mice (Figure 2C). The results show that the presence of feeder cells does not improve the vitality of $\mathrm{CD}^{+}$ and $\mathrm{CD}^{+}$liver $\operatorname{Trm}$, when incubated at $37^{\circ} \mathrm{C}$. Together, this suggests that the observed loss of Trm vitality upon incubation at $37^{\circ} \mathrm{C}$ is triggered via ARTC2.2-mediated ADP-ribosylation of $\mathrm{P} 2 \mathrm{X} 7$. In order to further probe this conclusion, we compared the vitality of isolated $\mathrm{CD}^{+}$and $\mathrm{CD}^{+}$Trm and Tem obtained from mice 7 weeks after Lm infection and analyzed the impact of injecting the ARTC2.2-blocking nanobody s+16a $30 \mathrm{~min}$ before sacrifice on cell vitality. For this, one group of mice was injected i.v. with $50 \mu \mathrm{g} \mathrm{s}+16 \mathrm{a} 30 \mathrm{~min}$ prior to sacrifice, the other group was left untreated as control. As shown before for liver Trm from naive mice, we observed that the vast majority $(85 \%)$ of $\mathrm{CD}^{+}$and $\mathrm{CD}^{+}$Trm of the untreated control group died during the $37^{\circ} \mathrm{C}$ incubation, compared to only $12 \%$ of CD $8^{+}$Tem and $26 \%$ of $\mathrm{CD}^{+}$Tem (Figure 2D). By contrast, $\mathrm{CD}^{+}$and $\mathrm{CD} 4^{+}$ Trm and Tem sorted from the s+16a-treated mice exhibited a preserved vitality with only $16 \%$ dead cells after incubation at $37^{\circ} \mathrm{C}$. Together, our results reveal the detrimental effects of preparation-related P2X7 ADP-ribosylation on liver Trm vitality upon incubation at $37^{\circ} \mathrm{C}$.

\section{Injection of s+16a Allows Cytokine Profiling of Liver Trm}

Our findings that the majority of isolated liver Trm succumb to cell death upon incubation at $37^{\circ} \mathrm{C}$ raises the question whether this affects functional assays that involve incubation steps at $37^{\circ} \mathrm{C}$ and impinges on the quality of the obtained data. To test this, we analyzed the cytokine expression profile of freshly sorted liver $\mathrm{CD}^{+}$and $\mathrm{CD}^{+}$Trm from s+16a-treated mice and untreated control mice 7 weeks after infection with $\mathrm{Lm}$ in a proof-ofprinciple experiment. We restimulated $1-2 \times 10^{4}$ isolated cells in vitro with PMA/ionomycin for $20 \mathrm{~h}$ and analyzed the cytokine expression profile in the cell supernatants using a 13-plex bead-based immunoassay designed to quantify $\mathrm{T}$ cell-specific cytokine responses. By this, we detected low concentrations of IFN- $\gamma$, TNF- $\alpha$, and IL- 2 in the supernatants of stimulated CD8 ${ }^{+}$ Trm and $\mathrm{CD}^{+}$Trm isolated from control mice (Figure 3A). Strikingly, $\mathrm{CD}^{+}$and $\mathrm{CD}^{+}$Trm isolated from s+16a-treated mice produced more than 100 -fold higher concentrations of
A
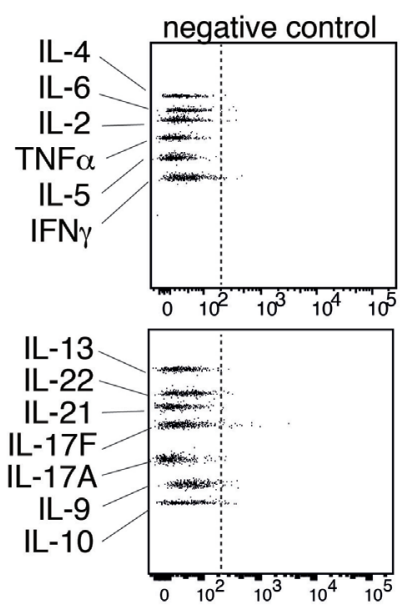

cytokine fluorescence

CD8 ${ }^{+}$Trm
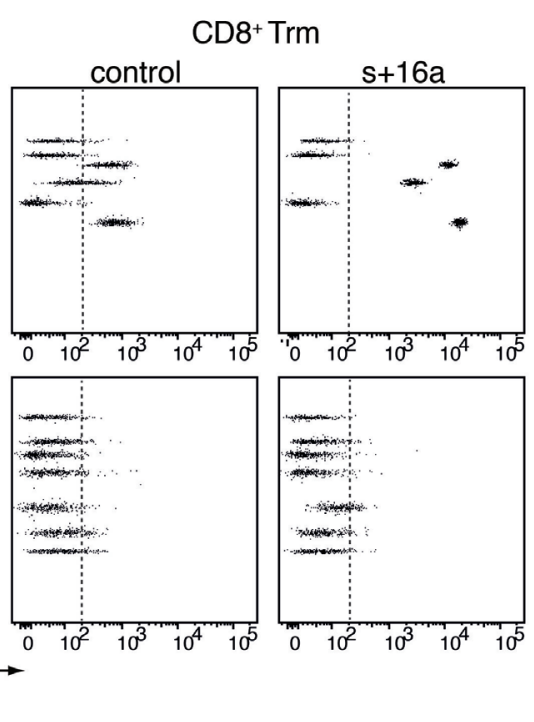

IL-4

TNF $\alpha$
$\mathrm{CD}^{+}{ }^{\mathrm{Trm}}$
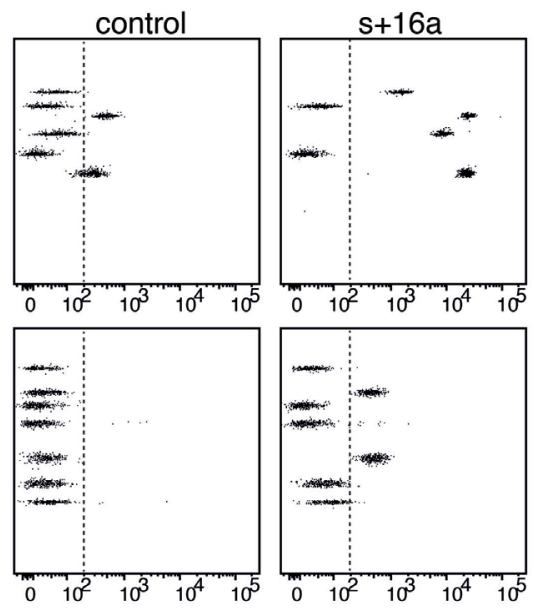

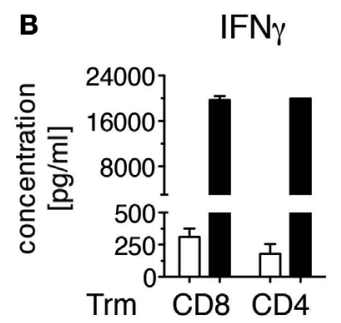

IL-2
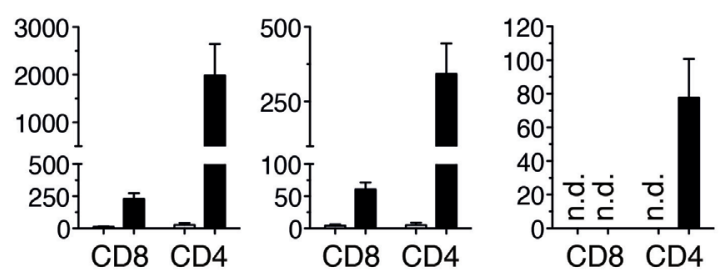

IL-17A

IL-22
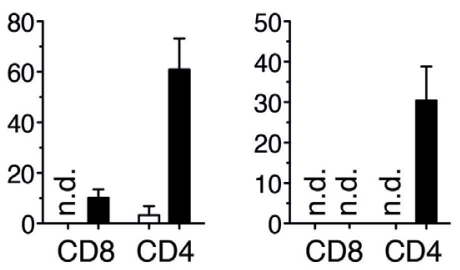

$\square$ control

s+16a

FIGURE 3 | In vitro cytokine expression profile of PMA/ionomycin stimulated liver Trm. (A) CD8+ $\left(1 \times 10^{4}\right.$ cells) and CD4+ $\left(2 \times 10^{4}\right.$ cells $)$ Trm from the liver of $\mathrm{Lm}^{+}$ infected mice were FACS sorted 7 weeks after infection. One group of mice was treated with $\mathrm{s}+16 \mathrm{a}$ prior to organ harvesting and the second group was left untreated as control. Cells were stimulated with PMA/ionomycin for $20 \mathrm{~h}$ and T cell cytokines [IFN $\gamma$, TNF $\alpha$, interleukin (IL)-2, IL-4, IL-21, IL-22, IL-17A, IL-17F, IL-10, IL-9, IL-5, and IL-13] were measured in the supernatants using a bead-based 13-plex assay. (B) The concentration of cytokines in the supernatants of stimulated $\mathrm{CD}^{+}$and $\mathrm{CD}^{+}$Trm from s+16a-treated and control mice $(n=3)$ was quantified. 
IFN- $\gamma$, TNF- $\alpha$, and IL-2 (Figure 3B). Furthermore, no IL-4 or IL-22 and only very low levels of IL-17A were detectable in the supernatants of stimulated $\mathrm{CD}^{+}{ }^{+}$Trm isolated from control mice. By contrast, $\mathrm{CD} 4^{+}$Trm harvested from s+16a-treated mice showed robust expression of IL-4, IL-22, and IL-17 upon PMA/ ionomycin stimulation (Figures 3A,B). Interestingly, IL-17A was also detectable in the supernatants of stimulated CD8 ${ }^{+}$Trm from s+16a-treated mice. These results demonstrate that ADPribosylation of $\mathrm{P} 2 \mathrm{X} 7$ during cell preparation reduces the vitality of Trm and therefore blunts their cytokine secretion during $37^{\circ} \mathrm{C} \mathrm{PMA} /$ ionomycin stimulation. This can limit the detection of low-level expressed cytokines, as demonstrated for IL-17A, IL-22, and IL-4.

\section{DISCUSSION}

Our results show that liver tissue-resident memory $\mathrm{T}$ cells (Trm) co-expresses high levels of ARTC2.2 and P2X7. The high ARTC2.2 expression enables ADP-ribosylation of Trm cell surface proteins during cell preparation from the liver in response to $\mathrm{NAD}^{+}$released during cell preparation. ARTC2.2 ADPribosylates the $\mathrm{P} 2 \mathrm{X} 7$ ion channel even if cells are prepared at $4^{\circ} \mathrm{C}$. Subsequent incubation of the isolated $\operatorname{Trm}$ at $37^{\circ} \mathrm{C}$ then induces P2X7 activation, resulting in cell death and making it difficult to use these cells during further in vitro assays. The consequences of preparation-related ADP-ribosylation on Trm resemble those of ARTC2.2 and P2X7 co-expressing Tregs and NKT cells, i.e., dramatic loss of cell vitality during in vitro culture (14). Our rescue approach, i.e., injection of the ARTC2.2-blocking nanobody $s+16$ a prior to sacrificing the mice, markedly preserves the vitality of $\operatorname{Trm}$ at $37^{\circ} \mathrm{C}$ incubation and allows sensitive in vitro cytokine expression profiling.

Several studies have shown that both, ARTC2.2 and P2X7 are differentially expressed among $\mathrm{T}$ cell subpopulations (15, 28-31). Downregulation of ARTC2.2 is observed by T cells upon $\mathrm{T}$ cell receptor activation (32). Similarly, recently activated T cells express lower levels of P2X7 compared to their naive counterparts (33). Both findings fit to the phenotype of liver CD69-KLRG1 ${ }^{+}$ Tem observed in the Lm infected mice. The physiological role of ARTC2.2 and P2X7 on Trm remain unclear. High P2X7 expression on Trm could be beneficial to boost $\mathrm{T}$ cell receptor signaling toward eliciting a $\mathrm{T}$ cell memory response during pathogen reencountering since $\mathrm{P} 2 \mathrm{X} 7$ can act as receptor for autocrine ATP stimulation to enhance IL-2 production (34). However, massive tissue damage during liver infection accompanied by the release $\mathrm{NAD}^{+}$would probably kill most of the liver Trm and thereby delay pathogen clearance. Therefore, further studies are needed to investigate the interplay between ARTC2.2 and P2X7 on Trm in vivo during a second course of infection. Furthermore, it needs to be investigated whether Trm from other organs also exhibit a high co-expression of ARTC2.2 and P2X7 and are vulnerable to NAD-induced cell death (NICD). A recent study by Yoshizawa et al. describes the transcriptome characterization of $\mathrm{CD} 9^{+} \mathrm{Trm}$ in the lung of influenza infected mice. Interestingly, the authors found a differential P2X7 expression in two Trm populations directed against the two immunodominant epitopes $\mathrm{PA}_{224-233} / \mathrm{H}$ $2 \mathrm{D}^{\mathrm{b}}$ and $\mathrm{NP}_{366-374} / \mathrm{H}-2 \mathrm{D}^{\mathrm{b}}$. $\mathrm{PA}_{224-233} / \mathrm{H}-2 \mathrm{D}^{\mathrm{b}}$ Trm exhibited pronounced $\mathrm{P} 2 \mathrm{X} 7 \mathrm{mRNA}$ expression in $\mathrm{CD}_{103^{-}}$and, at slightly lower level, in $\mathrm{CD}_{103^{+}}$cells. By contrast, P2X7 mRNA expression was virtually absent in $\mathrm{CD}_{103^{-}}$and $\mathrm{CD} 103^{+} \mathrm{NP}_{366-374} / \mathrm{H}-2 \mathrm{D}^{\mathrm{b}}$ Trm (35). Another study demonstrated that $\mathrm{CD} 4^{+} \mathrm{T}$ cells from the small intestine of naïve mice exhibit $\mathrm{P} 2 \mathrm{X} 7$ expression on $\mathrm{CD} 69^{+}$ cells (36). The latter were susceptible toward NICD as demonstrated by in vivo depletion after injection of $\mathrm{NAD}^{+}$, indicating that ARTC2.2 is co-expressed by these cells.

In general, it is advised to check the expression levels of ARTC2.2 and P2X7 when working with murine T cell populations. As a first approach, this can be done by querying public mRNA sequencing databases such as www.immgen.org (37). The results of such analyses reveal that Tregs, $\mathrm{CD} 4^{+}$memory T cells, and NKT cells from spleen and liver express high mRNA levels of Art2 and P2rx7. These cells can then be characterized for ARTC2.2 and P2X7 cell surface expression by flow cytometry or by functional assays that monitor P2X7-related effects such as ecto-domain shedding of CD27 and CD62L or phosphatidylserine externalization and PI uptake upon $37^{\circ} \mathrm{C}$ incubation (16). It is important to note that the human ARTC2 gene is nonfunctional due to premature stop codons and therefore ARTC2related effects observed in mice are not directly transferrable to humans (38).

ARTC2.2 ADP-ribosylates multiple targets on T cells, including CD25, the $\alpha$-chain of the high affinity IL-2 receptor (39). Here, ADP-ribosylation reduces binding of IL-2 and subsequent STAT5 signaling in Tregs. For $\mathrm{CD}^{+}$cytotoxic T cells, it has been shown that ARTC2.2-catalyzed ADP-ribosylation of CD8 diminishes the binding to MHC class I (40). Therefore, the beneficial effects of systemically injected ARTC2.2 blocking nanobody on Trm vitality and cytokine secretion may be mediated also in part by preventing ADP-ribosylation of these and other targets. A recently published study describes a mass-spectrometry-based approach to identify ADP-ribosylated proteins (41). This technique has been applied by our group to identify ADP-ribosylated cell surface target proteins on microglia (4) including several cell adhesion molecules. This technique could be utilized to analyze the ADP-ribosylome of T cells in order to identify other target proteins that are potentially influenced in their function by ADP-ribosylation.

One limitation of our approach to prevent ADP-ribosylation during $\mathrm{T}$ cell preparation using the $\mathrm{s}+16 \mathrm{a}$ nanobody is that it needs to be injected i.v. or i.p. into mice which may be technically challenging and requires the approval to perform animal experiments. A recent study suggests to use the P2X7 antagonist KN62 as alternative substance that can be used in vitro during the preparation of single-cell suspensions from lymphoid organs in order to protect $\mathrm{T}$ follicular helper and regulatory cells from NICD and further during in vitro culture of T cells (42). Indeed, this preserved the vitality of ARTC2.2 and P2X7 expressing T follicular helper and regulatory cells. However, P2X7 blockade by KN62 does not prevent the ADP-ribosylation of other membrane proteins during cell preparation. Moreover, blockade of $\mathrm{P} 2 \mathrm{X} 7$ might also interfere with $\mathrm{T}$ cell function, as autocrine ATP stimulation upon $\mathrm{T}$ cell receptor activation enhances the production of IL-2 via P2X7 activation (34). Furthermore, though KN62 is a highly potent non-competitive P2X7 antagonist (IC50: 
$15 \mathrm{nM}$ ), it is also cell permeable and a selective inhibitor for $\mathrm{Ca}^{2+} /$ calmodulin-dependent protein kinase II (IC50: $500 \mathrm{nM}$ ), which plays a role in T cell receptor mediated IkB kinase activation (43). Therefore, even though systemic injection of the s+16a nanobody approach is technically more elaborative, blocking of ARTC2.2 during cell preparation probably interferes less with $\mathrm{T}$ cell function compared to P2X7 blockade.

In a proof-of-principle experiment, we demonstrated that injection of $s+16$ a allows a sensitive ex vivo cytokine expression analyses of isolated Trm in response to polyclonal PMA/ ionomycin stimulation. By this, we could detect low-level cytokines expressed by CD4 ${ }^{+}$Trm such as IL-4, IL-17A, and IL-22 that were undetectable when $\mathrm{CD} 4^{+}$Trm were isolated from control mice that did not receive $s+16$ a treatment. It is likely that the reduced vitality of the isolated control $\mathrm{CD} 4^{+}$ Trm is responsible for this, however, we cannot rule out that tissue-resident T-helper type 1 (Th1), 2 (Th2), 17 (Th17), and 22 (Th22) cells are differentially affected by NICD. Indeed, P2X7 is highly expressed by intestinal Th1 and Th17 cells and injection of $\mathrm{NAD}^{+}$induces the depletion of these cells as it did for intestinal Tregs (36).

We conclude that when working with murine liver Trm, one needs to be aware that T cells expressing high levels of ARTC2.2 and P2X7 succumb to preparation-related ADP-ribosylation of P2X7 and other cell surface proteins that affects Trm vitality and function. Using our nanobody-based approach to block ARTC2.2 in vivo minimizes cell loss, paving the way for sensitive Trm cytokine expression profiling and other functional analyses.

\section{REFERENCES}

1. Glowacki G, Braren R, Firner K, Nissen M, Kühl M, Reche P, et al. The family of toxin-related ecto-ADP-ribosyltransferases in humans and the mouse. Protein Sci (2002) 11:1657-70. doi:10.1110/ps.0200602

2. Koch-Nolte F, Kernstock S, Mueller-Dieckmann C, Weiss MS, Haag F. Mammalian ADP-ribosyltransferases and ADP-ribosylhydrolases. Front Biosci (2008) 13:6716. doi:10.2741/3184

3. Hong S, Braß A, Seman M, Haag F, Koch-Nolte F, Dubyak GR. Basal and inducible expression of the thiol-sensitive ART2.1 ecto-ADP-ribosyltransferase in myeloid and lymphoid leukocytes. Purinergic Signal (2009) 5:369-83. doi:10.1007/s11302-009-9162-2

4. Rissiek B, Menzel S, Leutert M, Cordes M, Behr S, Jank L, et al. Ecto-ADPribosyltransferase ARTC2.1 functionally modulates Fc $\gamma$ R1 and Fc $\gamma$ R2B on murine microglia. Sci Rep (2017) 7:16477. doi:10.1038/s41598-017-16613-w

5. Seman M, Adriouch S, Scheuplein F, Krebs C, Freese D, Glowacki G, et al. NAD-induced T cell death: ADP-ribosylation of cell surface proteins by ART2 activates the cytolytic P2X7 purinoceptor. Immunity (2003) 19:571-82. doi:10.1016/S1074-7613(03)00266-8

6. Rissiek B, Haag F, Boyer O, Koch-Nolte F, Adriouch S. P2X7 on mouse T cells: one channel, many functions. Front Immunol (2015) 6:204. doi:10.3389/fimmu. 2015.00204

7. Nicke A, Kuan YH, Masin M, Rettinger J, Marquez-Klaka B, Bender O, et al. Functional P2X7 splice variant with an alternative transmembrane domain 1 escapes gene inactivation in P2X7 knock-out mice. J Biol Chem (2009) 284:25813-22. doi:10.1074/jbc.M109.033134

8. Schwarz N, Drouot L, Nicke A, Fliegert R, Boyer O, Guse AH, et al. Alternative splicing of the N-terminal cytosolic and transmembrane domains of P2X7 controls gating of the ion channel by ADP-ribosylation. PLoS One (2012) 7:e41269. doi:10.1371/journal.pone.0041269

9. Adriouch S, Bannas P, Schwarz N, Fliegert R, Guse AH, Seman M, et al. ADPribosylation at R125 gates the P2X7 ion channel by presenting a covalent

\section{ETHICS STATEMENT}

This study was carried out in accordance with the German animal welfare law. The protocol was approved by the Hamburger Behörde für Gesundheit und Verbraucherschutz, Veterinärwesen/ Lebensmittelsicherheit (approval number G17/17).

\section{AUTHOR CONTRIBUTIONS}

$\mathrm{BR}, \mathrm{ML}$, and FR performed the experiments and analyzed the data. TM, H-WM, and FK-N supervised the experiments and assisted with data interpretation and manuscript preparation. BR assembled the figures and wrote the manuscript, which has been reviewed by all authors.

\section{ACKNOWLEDGMENTS}

The authors would like to thank the HEXT FACS Core Facility (Hamburg, Germany) for cell sorting and the NIH tetramer core facility (Atlanta, GA, USA) for providing PE-conjugated CD1d-tetramer.

\section{FUNDING}

This work was supported by a faculty grant to BR (FFM, NWF17/07), grants from the Deutsche Forschungsgemeinschaft to FK-N (No 310/11-1, SFB1192), H-WM (SFB841, SFB1192), and FR (RA 2893/2), and a grant from "Hermann und Lilly SchillingStiftung für Medizinische Forschung” to TM.

ligand to its nucleotide binding site. FASEB J (2008) 22:861-9. doi:10.1096/ fj.07-9294com

10. $\mathrm{Gu} \mathrm{B}$, Bendall LJ, Wiley JS. Adenosine triphosphate-induced shedding of CD23 and L-selectin (CD62L) from lymphocytes is mediated by the same receptor but different metalloproteases. Blood (1998) 92:946-51.

11. Moon H, Na H-Y, Chong KH, Kim TJ. P2X7 receptor-dependent ATP-induced shedding of CD27 in mouse lymphocytes. Immunol Lett (2006) 102:98-105. doi:10.1016/j.imlet.2005.08.004

12. Scheuplein F, Schwarz N, Adriouch S, Krebs C, Bannas P, Rissiek B, et al. $\mathrm{NAD}+$ and ATP released from injured cells induce P2X7-dependent shedding of CD62L and externalization of phosphatidylserine by murine $\mathrm{T}$ cells. J Immunol (2009) 182:2898-908. doi:10.4049/jimmunol.0801711

13. Bruzzone S, Guida L, Zocchi E, Franco L, De Flora A. Connexin 43 hemi channels mediate $\mathrm{Ca} 2+$-regulated transmembrane $\mathrm{NAD}+$ fluxes in intact cells. FASEB J (2001) 15:10-2. doi:10.1096/fj.00-0566fje

14. Rissiek B, Danquah W, Haag F, Koch-Nolte F. Technical advance: a new cell preparation strategy that greatly improves the yield of vital and functional Tregs and NKT cells. J Leukoc Biol (2014) 95:543-9. doi:10.1189/ jlb.0713407

15. Hubert S, Rissiek B, Klages K, Huehn J, Sparwasser T, Haag F, et al. Extracellular NAD+ shapes the Foxp3+ regulatory T cell compartment through the ART2P2X7 pathway. J Exp Med (2010) 207:2561-8. doi:10.1084/jem.20091154

16. Rissiek B, Haag F, Boyer O, Koch-Nolte F, Adriouch S. ADP-ribosylation of P2X7: a matter of life and death for regulatory T cells and natural killer T cells. Curr Top Microbiol Immunol (2015) 384:107-26. doi:10.1007/ 82_2014_420

17. Koch-Nolte F, Reyelt J, Schössow B, Schwarz N, Scheuplein F, Rothenburg S, et al. Single domain antibodies from llama effectively and specifically block T cell ecto-ADP-ribosyltransferase ART2.2 in vivo. FASEB J (2007) 21:3490-8. doi:10.1096/fj.07-8661com

18. Schenkel JM, Masopust D. Tissue-resident memory T cells. Immunity (2014) 41:886-97. doi:10.1016/j.immuni.2014.12.007 
19. Mackay LK, Rahimpour A, Ma JZ, Collins N, Stock AT, Hafon M-L, et al. The developmental pathway for CD103(+)CD8+ tissue-resident memory T cells of skin. Nat Immunol (2013) 14:1294-301. doi:10.1038/ni.2744

20. Fernandez-Ruiz D, Ng WY, Holz LE, Ma JZ, Zaid A, Wong YC, et al. Liverresident memory $\mathrm{CD} 8+\mathrm{T}$ cells form a front-line defense against malaria liver-stage infection. Immunity (2016) 45:889-902. doi:10.1016/j.immuni. 2016.08.011

21. Ohlrogge W, Haag F, Löhler J, Seman M, Littman DR, Killeen N, et al. Generation and characterization of ecto-ADP-ribosyltransferase ART2.1/ ART2.2-deficient mice. Mol Cell Biol (2002) 22:7535-42. doi:10.1128/MCB. 22.21.7535-7542.2002

22. Solle M, Labasi J, Perregaux DG, Stam E, Petrushova N, Koller BH, et al. Altered cytokine production in mice lacking P2X(7) receptors. J Biol Chem (2001) 276:125-32. doi:10.1074/jbc.M006781200

23. Mombaerts P, Iacomini J, Johnson RS, Herrup K, Tonegawa S, Papaioannou VE. RAG-1-deficient mice have no mature B and T lymphocytes. Cell (1992) 68:869-77. doi:10.1016/0092-8674(92)90030-G

24. Foulds KE, Zenewicz LA, Shedlock DJ, Jiang J, Troy AE, Shen H. Cutting edge: CD4 and CD8 T cells are intrinsically different in their proliferative responses. J Immunol (2002) 168:1528-32. doi:10.4049/jimmunol.168.4.1528

25. Galkina E, Thatte J, Dabak V, Williams MB, Ley K, Braciale TJ. Preferential migration of effector CD8+ T cells into the interstitium of the normal lung. J Clin Invest (2005) 115:3473-83. doi:10.1172/JCI24482

26. Koch-Nolte F, Duffy T, Nissen M, Kahl S, Killeen N, Ablamunits V, et al. A new monoclonal antibody detects a developmentally regulated mouse ecto-ADP-ribosyltransferase on T cells: subset distribution, inbred strain variation, and modulation upon T cell activation. J Immunol (1999) 163:6014-22.

27. Möller S, Jung C, Adriouch S, Dubberke G, Seyfried F, Seman M, et al. Monitoring the expression of purinoceptors and nucleotide-metabolizing ecto-enzymes with antibodies directed against proteins in native conformation. Purinergic Signal (2007) 3:359-66. doi:10.1007/s11302-007-9084-9

28. Aswad F, Kawamura H, Dennert G. High sensitivity of CD4+CD25+ regulatory $\mathrm{T}$ cells to extracellular metabolites nicotinamide adenine dinucleotide and ATP: a role for P2X7 receptors. J Immunol (2005) 175:3075-83. doi:10.4049/ jimmunol.175.5.3075

29. Aswad F, Dennert G. P2X7 receptor expression levels determine lethal effects of a purine based danger signal in T lymphocytes. Cell Immunol (2006) 243:58-65. doi:10.1016/j.cellimm.2006.12.003

30. Kawamura H, Aswad F, Minagawa M, Govindarajan S, Dennert G. P2X7 receptors regulate NKT cells in autoimmune hepatitis. JImmunol (2006) 176:2152-60. doi:10.4049/jimmunol.176.4.2152

31. Proietti M, Cornacchione V, Rezzonico Jost T, Romagnani A, Faliti CE, Perruzza L, et al. ATP-gated ionotropic P2X7 receptor controls follicular T helper cell numbers in Peyer's patches to promote host-microbiota mutualism. Immunity (2014) 41:789-801. doi:10.1016/j.immuni.2014.10.010

32. Kahl S, Nissen M, Girisch R, Duffy T, Leiter EH, Haag F, et al. Metalloproteasemediated shedding of enzymatically active mouse ecto-ADP-ribosyltransferase ART2.2 upon T cell activation. J Immunol (2000) 165:4463-9. doi:10.4049/ jimmunol.165.8.4463
33. Adriouch S, Hubert S, Pechberty S, Koch-Nolte F, Haag F, Seman M. NAD+ released during inflammation participates in $\mathrm{T}$ cell homeostasis by inducing ART2-mediated death of naive T cells in vivo. J Immunol (2007) 179:186-94. doi:10.4049/jimmunol.179.1.186

34. Schenk U, Westendorf AM, Radaelli E, Casati A, Ferro M, Fumagalli M, et al. Purinergic control of T cell activation by ATP released through pannexin-1 hemichannels. Sci Signal (2008) 1:ra6. doi:10.1126/scisignal.1160583

35. Yoshizawa A, Bi K, Keskin DB, Zhang G, Reinhold B, Reinherz EL. TCRpMHC encounter differentially regulates transcriptomes of tissue-resident CD8 T cells. Eur J Immunol (2018) 48:128-50. doi:10.1002/eji.201747174

36. Hashimoto-Hill S, Friesen L, Kim M, Kim CH. Contraction of intestinal effector T cells by retinoic acid-induced purinergic receptor P2X7. Mucosal Immunol (2017) 10:912-23. doi:10.1038/mi.2016.109

37. Heng TSP, Painter MW; Immunological Genome Project Consortium. The Immunological Genome Project: networks of gene expression in immune cells. Nat Immunol (2008) 9:1091-4. doi:10.1038/ni1008-1091

38. Haag F, Koch-Nolte F, Kühl M, Lorenzen S, Thiele HG. Premature stop codons inactivate the RT6 genes of the human and chimpanzee species. J Mol Biol (1994) 243:537-46. doi:10.1006/jmbi.1994.1680

39. Teege S, Hann A, Miksiewicz M, MacMillan C, Rissiek B, Buck F, et al. Tuning IL-2 signaling by ADP-ribosylation of CD25. Sci Rep (2015) 5:8959. doi:10.1038/srep08959

40. Lischke T, Schumacher V, Wesolowski J, Hurwitz R, Haag F, Koch-Nolte F, et al. CD8- $\beta$ ADP-ribosylation affects CD8(+) T-cell function. Eur J Immunol (2013) 43:1828-38. doi:10.1002/eji.201243231

41. Martello R, Leutert M, Jungmichel S, Bilan V, Larsen SC, Young C, et al. Proteome-wide identification of the endogenous ADP-ribosylome of mammalian cells and tissue. Nat Commun (2016) 7:12917. doi:10.1038/ncomms12917

42. Georgiev H, Ravens I, Papadogianni G, Malissen B, Förster R, Bernhardt G. Blocking the ART2.2/P2×7-system is essential to avoid a detrimental bias in functional CD4 T cell studies. Eur J Immunol (2018) 48:1078-81. doi:10.1002/ eji. 201747420

43. Bui JD, Calbo S, Hayden-Martinez K, Kane LP, Gardner P, Hedrick SM. A role for CaMKII in T cell memory. Cell (2000) 100:457-67. doi:10.1016/ S0092-8674(00)80681-9

Conflict of Interest Statement: FK-N receives royalties from sales of antibodies developed in the lab via MediGate $\mathrm{GmbH}$, a $100 \%$ subsidiary of the University Medical Center, Hamburg. All other authors declare that the research was conducted in the absence of any commercial or financial relationships that could be construed as a potential conflict of interest. Nanobody s+16a can be obtained via material transfer agreement from FK-N.

Copyright (c) 2018 Rissiek, Lukowiak, Raczkowski, Magnus, Mittrücker and Koch-Nolte. This is an open-access article distributed under the terms of the Creative Commons Attribution License (CC BY). The use, distribution or reproduction in other forums is permitted, provided the original author(s) and the copyright owner(s) are credited and that the original publication in this journal is cited, in accordance with accepted academic practice. No use, distribution or reproduction is permitted which does not comply with these terms. 